\section{Mª Teresa González de Garay}

Profesora Titular de Literatura Española e Hispanoamericana en la Universidad de La Rioja (España). Ha publicado estudios sobre poesía barroca (F. López de Zárate), narrativa del exilio republicano (Paulino Masip, Max Aub, Ramón J. Sender, Eugenio F. Granell, Patricio P. Escobal, Carlos Blanco Aguinaga o María Teresa León) y poesía y narrativa hispanoamericanas (Jorge Teillier, Alejo Carpentier, Carmen Ollé, Rossella di Paolo, Mayra Montero, Renée Ferrer o Carlos Fuentes). Es miembro de Gexel desde 1997 (Grupo de Estudios del Exilio Literario. Universidad Autónoma de Barcelona).

1

Gertrudis Gómez de Avellaneda, Obras, I, Biblioteca de Autores Españoles, Tomo CCLXXII, Madrid, Atlas, 1974, pág. 229.

2

Gertrudis Gómez de Avellaneda, Dos mujeres, La Habana, Editorial Letras Cubanas, Instituto Cubano del Libro, 2000. Véase el sugerente artículo de Nancy LaGreca, "Literatura y conciencia: El suicidio femenino en el Álbum Cubano de lo Bueno y lo Bello (1860) y Dos mujeres (1842-1843) de Gertrudis Gómez de Avellaneda», Revolución y Cultura, 4 (2006), pp. 12-16.

3

Teodosio Fernández, «La conquista de América en la novela hispanoamericana del siglo XIX.

El caso de México», América sin nombre, Recuperaciones del mundo precolombino y colonial, 5-6 (2004), p. 72.

4

Gertrudis Gómez de Avellaneda, Sab, Salamanca, Anaya, 1970, p. 33.

5

Emilio Cotarelo y Mori, La Avellaneda y sus obras, Madrid, Tipografía de Archivos, 1930, p. 392. Tomo la cita de José Servera, en Gertrudis Gómez de Avellaneda, Sab, Letras Hispánicas, Madrid, Cátedra, 1997, p. 47.

Gertrudis González de Avellaneda: un relato sobre Hernán Cortés Ma TERESA GONZÁLEZ DE GARAY

\title{
GERTRUDIS GÓMEZ DE AVELLANEDA: UN RELATO SOBRE HERNÁN CORTÉS
}

\author{
$M^{a}$ TERESA GONZÁLEZ DE GARAY
}

De 1869 a 1871, los Sucesores de Rivadeneyra editaban en Madrid unas Obras literarias, dramáticas y poéticas de Gertrudis Gómez de Avellaneda, en seis volúmenes, revisadas por la propia autora ${ }^{1}$. Entre esos volúmenes se encontraban dos, el IV y el $\mathrm{V}$, dedicados a Novelas y leyendas. Pero en ninguno de esos dos volúmenes aparecían ni $S a b$, la hoy relativamente valorada novela sentimental de corte antiesclavista, que publicara la Avellaneda en 1841, con apenas 27 años, ni Dos mujeres, la otra narración extensa en la línea del sentimentalismo romántico, mucho menos atractiva para la crítica, que se edita en los años 1842-1843, y que reapareció, al fin, el año 2000 en Letras Cubanas, La Habana, con un interesante prólogo de Antón Arrufat², ni tampoco el Guatimozín, un amplio relato basado en la conquista de México por Hernán Cortés, y que se inscribe, por tanto, en el género histórico, walterscottiano, aunque con el marchamo indianista, "quizá la novela de mayor interés entre cuantas durante el siglo XIX, en España y en Hispanoamérica, recrearon los tiempos de la conquista», como afirma Teodosio Fernández ${ }^{3}$, y que se daba a conocer al público lector en El Heraldo de Madrid entre el 21 de febrero y el 25 de abril de 1846. Es cierto que le quedaban en el campo de la prosa creativa a Gómez de Avellaneda un puñado de Leyendas y alguna que otra novela corta, pero su producción narrativa de mayor aliento quedaba así proscrita, de alguna manera, por la propia autora, ya fuera por razones intrínsecas, derivadas de su voluntad literaria o ideológica, ya por razones extrínsecas, por imposiciones del medio en el que se desenvolvía. Y las consecuencias, a corto y medio plazo, suponían un daño irreparable para la ubicación de la autora en el lugar cualitativo e histórico que le correspondía, y para el conocimiento de su obra por las generaciones posteriores. Nada nos extraña, por tanto, que Gertrudis Gómez de Avellaneda, al menos en tanto que novelista, se haya convertido estrictamente en carne de academicismo investigador.

Pero habría, a mi entender, que diferenciar en este juego de olvidos voluntarios, o de desdenes secretos, entre sus dos novelas iniciales, Sab y Dos mujeres, y la más madura y sólida, Guatimozin. Respecto a las primeras, ni un solo dato personal procedente de la autora ayuda a resolver el enigma. De ahí que la crítica haya buscado motivaciones externas, especialmente las derivadas del ambiente socioeconómico y político de la España coetánea. Respecto a $S a b$, desde la edición de La Habana de 1883, en la revista El Museo, todos los sucesivos editores reproducen la nota de aquella:

Se publicó en Madrid, en 1841; pero la corta edición que se hizo fue, en su mayor parte, secuestrada y retirada de la circulación por los mismos parientes de la autora, a causa de las ideas abolicionistas que encierra. Por la misma causa fue excluida de la edición completa de las obras de la Avellaneda, ya que de seguro se le habría negado la entrada en esta isla, si hubiera figurado Sab en ella ${ }^{4}$.

Al margen de la negativa de Emilio Cotarelo a aceptar estos datos («no consta que la novela haya sido retirada del público por los parientes de la autora ni por nadie. En mi juventud recuerdo haberla visto en casi todos los baratillos de libros de Madrid» $»^{5}$ ), parece lógico sospechar que las condiciones específi- 
cas de la España de 1869, en pleno auge de «La Gloriosa», la revolución de 1868, no eran más espinosas que las que predominaran en 1841, durante la Regencia de Espartero. Y, ¿por qué la problemática esclavista iba a ser un obstáculo insuperable en 1869 , si ya no lo era en absoluto en 1883, a la hora de simplemente editar una novela, donde ni siquiera se ponían en cuarentena los lineamientos básicos de la política cubana en relación con la metrópoli? Ciertamente, en 1844, en la Real Aduana de Santiago de Cuba fueron retenidos ejemplares de $S a b$ y de Dos mujeres, y así lo hizo constar en su edición de Sab Mary Cruz, con el fragmento del Expediente depositado en el Archivo de Asuntos políticos de La Habana (Legajo 42, documento $\mathrm{n}^{\circ} 8$ ), que también reproduce la edición de José Servera: «No pueden introducirse [Sab y Dos mujeres] por contener las primeras doctrinas subversivas del sistema de esclavitud de esta Isla y contrarias a la moral y buenas costumbres, y la segunda por estar plagada de doctrinas inmorales» ${ }^{6}$. Esto ocurría en Septiembre de 1844, y el 14 de enero de 1845, Manuel Gómez de Avellaneda, el hermano pequeño y predilecto de Gertrudis, que era el portador del baúl de libros prohibidos, con 84 ejemplares de $S a b$ y 75 de Dos mujeres, embarcaba de vuelta hacia Cádiz'.

¿Continuaban aún expedientadas las novelas de la Avellaneda 25 años después? ¿Y qué importaban en 1869 , en 1870 o en 1871 , los problemas de la exportación a Cuba de las narraciones de Gertrudis Gómez de Avellane$\mathrm{d}$ a, para que ésta se decidiera o no a incluirlas en el correspondiente volumen de su obra literaria? ¿También las doctrinas inmorales hipotéticas de Dos mujeres continuaban escandalizando a los bienpensantes criollos de la sociedad habanera? Todos estos elementos nos llevan a situar la negativa de la Avellaneda en el área de su conciencia, de su conciencia literaria de escritora, o de su conciencia moral de persona.

Dos textos de literatura devota, en el sentido más estricto del término, conocemos hoy salidos de la pluma de Gertrudis Gómez de Avellaneda. Ambos se sitúan cronológicamente en dos momentos decisivos de la vida de la escritora. El primero, tras el nacimiento y muerte de su hija ilegítima Brenhilde (abril y noviembre de 1845 , respectivamente), su matrimonio, el 10 de mayo de 1846 con Pedro Sabater, y la muerte de este último el 1 de agosto del mismo año en Burdeos. Unos meses de retiro en el convento de Nuestra
Señora de Loreto de la ciudad francesa, marcan, como indica Carmen Bravo-Villasante, «un cambio en las ideas religiosas de la Avellaneda, que eran poco claras y seguras» ${ }^{8}$. Y la consecuencia de esta situación será el perdido "devocionario», reencontrado por Cotarelo en 1930 en la Biblioteca Menéndez y Pelayo de Santander, y editado en 1975 como $M a-$ nual del cristiano por Carmen Bravo-Villasante. Peripecias editoriales impidieron que la Avellaneda lo editara en 1847, y que recuperara el original. Después, la Avellaneda rehace su vida, y sigue su carrera de exitosa dramaturga y creadora de relatos. Pero hay otra crisis posterior, ya definitiva de algún modo, la que se produce tras el postrero viaje a Cuba, en el año 1859. Llega a Cuba el 24 de noviembre de ese año, acompañada de su segundo marido, Domingo Verdugo. El 5 de diciembre, a los pocos días, muere su madre, doña Francisca de Arteaga; tres años más tarde, el 28 de octubre de 1863, fallece Domingo Verdugo en Pinar del Río. Gertrudis Gómez de Avellaneda intenta ingresar en un convento, pero acaba por regresar a España instada por su hermano Manuel, durante el verano de $1864^{\circ}$. No hay convento, por tanto, en esta segunda crisis, pero si habrá Devocionario, el editado en 1867, en Sevilla, con el título Devocionario nuevo y completísimo en prosa y verso, precisamente cuando está iniciando la preparación de sus Obras Literarias. Ahora, el escrúpulo religioso y la llamada de la conciencia moral son mucho más perentorios, porque se une a ellos la enfermedad crónica y porque pesa sobre la autora el vendaval del olvido. Es en esta coyuntura donde hay que situar su rechazo a reproducir editorialmente textos como el de Sab o, más aún, el de Dos mujeres y no, a mi entender, en circunstancias de índole censora, política o administrativa. La censura procede, en todo caso, de su propia posición moral. Aunque eso no le lleve a negar la autoría de sus obras, o a la prohibición de posibles impresiones en el futuro. En definitiva, y aunque se nos antoje impertinente o absurdo, ejerce su derecho de creación desde el ángulo negativo, como lo ejerciera, por ejemplo, Juan Ramón Jiménez, tratando de eliminar de los tenderetes
Gertrudis Gómez de Avellaneda, Sab, La Habana, editorial Arte y Literatura, Instituto Cubano del Libro, 1976, p. 52.

7

Servera, op. cit., pp. 47-48

8

Gertrudis Gómez de Avellaneda Manual del cristiano. Nuevo y completo devocionario, Madrid Fundación Universitaria Española, 1975, p. 7.

Servera, op. cit., pp. 37-38.

Gertrudis González de Avellaneda:

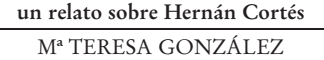

un relato sobre Hernán Cortés DE GARAY 


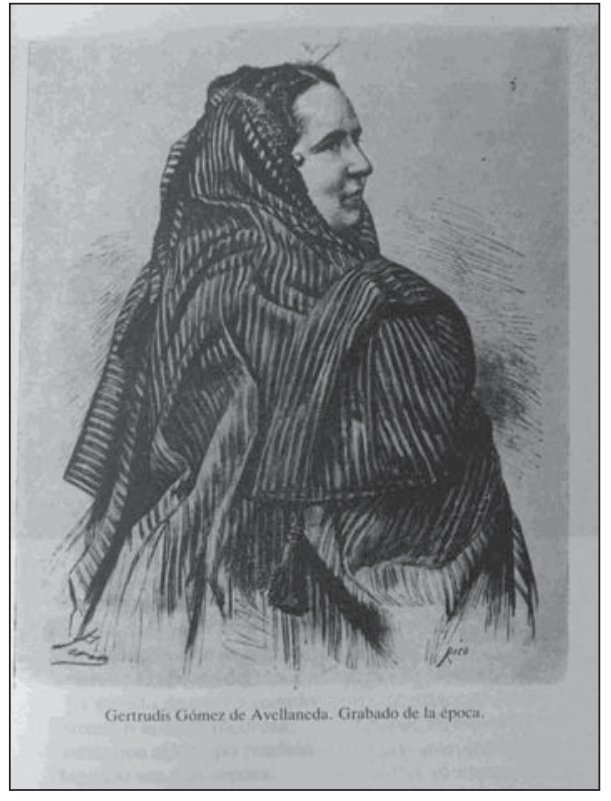

Retrato de Gertrudis Gómez de Avellaneda. de libros sus obras líricas del primer periodo, seguramente conducido por prejuicios morales cercanos tal vez, en algún sentido, a los de Gertrudis Gómez de Avellaneda, o como asimismo lo pusiera en práctica Vicente Blasco Ibáñez, proscribiendo durante su vida la reproducción legal de sus folletones juveniles, entre los que se incluía nada menos que La araña negra.

Pero muy otro, a mi juicio, va a ser el caso de Guatimozín, que es el que, en última instancia, nos interesa de modo singular, porque de él (del Guatimozín) se desprende Una anécdota de la vida de Cortés, el breve relato que constituye el motivo de 10 Benito Varela Jácome, Asedios a la literatura cubana. Textos y contextos, Santiago de Compostela, Universidade de Santiago de Compostela, 2002, p. 68.

11

Gertrudis Gómez de Avellaneda, Obras, $V$, edición, y estudio preliminar de D. José María Castro y Calvo, Biblioteca de Autores Españoles, Tomo CCLXXXVIII, Madrid, Atlas, 1981, p. 207.

12

Winston A. Reynolds, Hernán Cortés en la literatura del Siglo de Oro, Centro iberoamericano de Cooperación, Madrid, Editora Nacional, 1978, p. 307

13

Ibid., p. 303

14

Id.

Gertrudis González de Avellaneda: un relato sobre Hernán Cortés

M TERESA GONZÁLEZ DE GARAY mi artículo. En esta ocasión, como recuerda Valera Jácome en su «Función de lo fantástico en dos leyendas de Gómez de Avellaneda»: «La autora practica la intertextualidad en Una anécdota de Cortés, entresacada de su propia novela histórica Guatimozín» ${ }^{10}$. Y esta intertextualidad se produce en el mismo momento en que elimina de sus obras reunidas las dos novelas «peligrosas», y prescinde asimismo de la novela histórica indianista como tal, en su ser narrativo propio y completo. Pero la pequeña secuela cortesiana es una prueba irrecusable de que, contrariamente a los otros dos casos, Guatimozín no está olvidada. Por si no fuera suficiente la existencia del texto que traiciona las nostalgias de la Avellaneda, una nota de la autora, en tercera persona, para que ostente el carácter ambiguo de nota editorial, trata de justificar la no inclusión en los volúmenes publicados de la novela original. Dice la nota: «Esta anécdota, tomada de su novela Guatimozín, es lo único que la autora ha querido conservar de dicha obra, suprimida de la presente Colección a causa de no haberle permitido su falta de salud revisarla y corregirla, según juzgó necesario» ${ }^{11}$. Naturalmente, si la carencia de alusiones a las otras dos novelas largas propició las interpretaciones que anteriormente apuntamos, la presencia ahora de una desmañada y casi volandera nota no ha satisfecho a la crítica. En todo caso, ha favorecido el análisis del Guatimozín desde el punto de vista histórico e ideológico, aunque tal vez haya servido poco desde la estricta perspectiva literaria. Pero es que el tema de
Hernán Cortés sigue siendo, a este y otro lado del Atlántico, mucho más que literatura. Casi a quinientos años vista, continúa suscitando la pasión partidista e incluso maniquea.

De 1978 data el libro de Winston A. Reynolds, Hernán Cortés en la literatura del Siglo de Oro, un sugestivo trabajo sobre las relaciones entre literatura, historia y realidad, probablemente al margen de la voluntad del propio investigador. Al incluir Reynolds entre sus fuentes, no sólo la poesía épica y el romancero nuevo, el teatro y la novela -siempre dentro de los márgenes de los siglos XVI y XVII-, sino también el ensayo político, sociológico o científico, los cronistas de Indias, desde el propio protagonista, Cortés, en sus Cartas de Relación, hasta Bernal Díaz del Castillo o López de Gómara, sin olvidar a los historiadores humanistas de la talla de Fernández de Oviedo o Antonio de Solís y Rivadeneyra, nos obliga a sospechar que todavía sigue vigente el concepto literario de los clásicos, que incluía en los manuales a Jenofonte, Tito Livio y Flavio Josefo, o lo que todavía resulta más apasionante, que la literatura pura también es historia, o que la historia sesuda y erudita no deja de ser, en el último rincón del paraíso, ficción literaria. Reynolds no distingue entre apasionados y detractores furibundos de Cortés. A todos trata por igual y con idéntica parsimonia. A los clásicos y a los contemporáneos. Y si asegura, de una parte, que «una actitud reveladora en especial, de los escritores españoles, es su siempre presente fascinación con lo extraordinario encontrado en Cortés» ${ }^{12}$, no duda tampoco en afirmar que «la preferencia por enfrentar a Cortés con Cuauhtémoc, más bien que con Moctezuma, continúa aún hoy» ${ }^{13}$. Y recuerda las palabras de Pérez Martínez, al término de su libro sobre Cuauhtémoc: «Ha terminado la guerra sobre la tierra; pero el conflicto entre Cuauhtémoc y Cortés vive en nuestra sangre sin que alguno de los dos haya podido vencer (...) ambos fueron hombres de dos mundos que en nosotros se reconcilian y luchan» ${ }^{14}$. $\mathrm{Y}$ ese insepulto Cuauhtémoc, no lo olvidemos, es precisamente el Guatimozín de La Avellaneda, que se enfrenta a Cortés en el momento final de la novela, y que sigue protagonizando desde la horca Una anécdota de la vida de Cortés.

Esa fascinación por Cortés que Reynolds subraya, no sólo es característica de los escritores españoles del XVI y XVII, sino que se prolonga en el tiempo hasta épocas muy posteriores. Teodosio Fernández, en su trabajo 
ya citado, sobre La conquista de América en la novela hispanoamericana del siglo XIX. El caso de México, analiza las posiciones narrativas y psicológicas de la Avellaneda respecto a Cortés en la novela Guatimozín. Indica, primero,

que despierta en la autora sentimientos contradictorios. Se resalta su habilidad, (su doblez), para conseguir aliados o reducir al emperador mexicano, su crueldad frecuente, su condición ambiciosa, su fanatismo religioso y su política del terror (en expresión de la propia autora) (...). El héroe y el bandido (...) confluían efectivamente en Cortés (...). Sin embargo, todos los demás personajes quedaban oscurecidos por su tenacidad, su valor y su habilidad, hasta convertirse también en la novela 'en una de las más grandes figuras que puede presentar la historia', en 'tipo notable de su nación en aquel siglo en que era grande, guerrera, heroica, fanática y temeraria’» ${ }^{15}$.

Queda perfectamente claro. La consabida fascinación alegada por Reynolds surgía incontenible de la pluma de Gertrudis Gómez de Avellaneda. Para Teodosio Fernández, esta atracción por la aventura de Cortés y por su carácter, estaba también presente en la historiografía del siglo XIX, y recuerda el caso paradigmático de William H. Prescott, autor de una conocida Historia de la conquista de México, donde se presentaba la campaña de Cortés «como un episodio más novelesco que histórico», al considerar que aquel hecho de armas «ejecutado por un puñado de aventureros faltos de todo», era «un suceso casi milagroso que se desvía aun de las posibilidades que requiere la fábula, y que no admite paralelo en las páginas de la historia» ${ }^{16}$. Y esa fascinación sólo se contrapesaba con el protagonismo de Guatemozín, modelo de patriotismo al modo liberal, dispuesto a entregar su vida por el pueblo mexica, de cuya independencia política y cultural se considera responsable. No olvidemos que en 1846, año de la aparición pública de la novela, la América española está en pleno proceso político nacionalista, desde México, en el norte, a la Tierra de Fuego, en el sur, con la excepción precisamente de las dos islas caribeñas, Cuba y Puerto Rico, donde ya se perfilan los movimientos de emancipación. Guatimozín no se sustrae, no puede sustraerse, a esta corriente de afirmación nacional, cuyo punto de partida, por otra parte, está en Europa occidental. La propia España, desde la guerra napoleónica, conocida como «de la Independencia», entre 1808 y 1814, transita por esos derroteros de descubrimiento de una

moderna conciencia nacional, en la que el pasado juega, sin duda, un papel relevante. También el pasado de los conquistadores y colonizadores. También el pasado de Hernán Cortés y Moctezuma, y Guatimozín, o Cuauhtémoc, tanto monta.

¿Tendrá todo esto que ver con la negativa a reeditar su novela en 1869 por parte de Gertrudis Gómez de Avellaneda? ¿Y con la nota que intenta justificarla? En sus Dos palabras al lector, al comienzo de la novela Sab, la Avellaneda, tras indicar que «tres años ha dormido esta novelita casi olvidada en el fondo de su papelera», es decir entre 1838

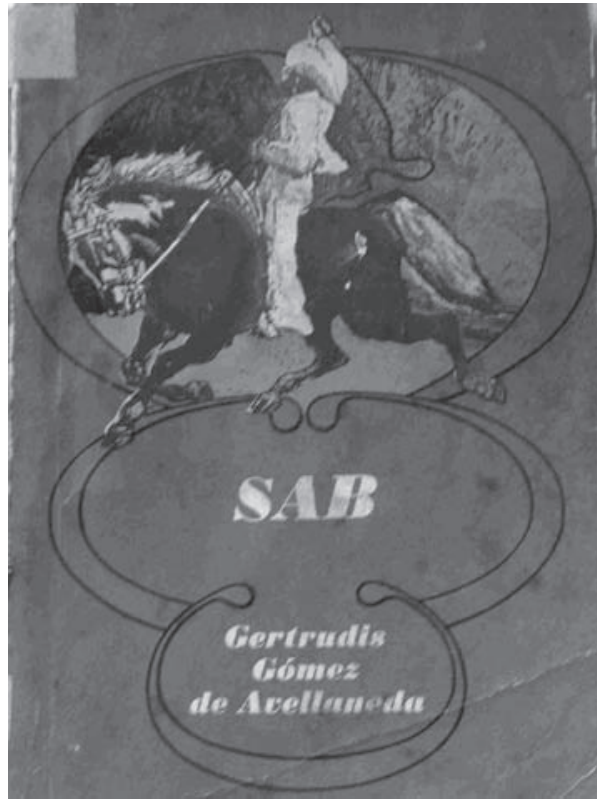

Portada de Sab. y 1841, año este último de su

publicación, asegura que «sea por pereza, sea por la repugnancia que sentimos en alterar lo que hemos escrito con una verdadera convicción (aun cuando ésta llegue a vacilar), la autora no ha hecho ninguna mudanza en sus borradores primitivos» ${ }^{17}$. José Servera, en el estudio introductorio a su edición de la novela, concluye: «Ella había afirmado (...) que le repugnaba cambiar lo que había escrito con convicción; lo cual hace suponer que sólo lo escrito sin esa convicción le parecía alterable. Esto explica (...) la exclusión de las novelas, que prefirió olvidar antes que transformarlas en lo que no eran» ${ }^{18}$. Sin entrar en disquisiciones sobre las sinceridades de la autora en el prólogo a $S a b$, entendemos las «Dos palabras», como una ingenua manifestación de captatio benevolentiae, que nos ha recordado tantas y tantas falsas modestias de creadores literarios, cuando reeditan, décadas después, sus escritos juveniles.

Por otra parte, resulta que Gertrudis Gómez de Avellaneda, al publicar Una anécdota de la vida de Cortés en 1869, transformaba «en lo que no eran» determinadas páginas de Guatimozín, y prefería no olvidar aquella novela. Por lo que la explicación de Servera parece inservible para el caso. Teodosio Fernández apunta que

las novelas españolas dedicadas a la conquista de México o primeros tiempos de la colonia, permiten comprobar que hasta la fecha de esa edición se habían impuesto actitudes conservadoras cada vez más acentuadas, desde las cuales los planteamientos liberales,
15 Fernández, op. cit., p. 74 16 lbid., pp. 74-75.

17 Bravo-Villasante, op. cit., 1970 p. 37

18 Servera, op.. cit., pp. 48-49.
Gertrudis González de Avellaneda: un relato sobre Hernán Cortés Ma TERESA GONZÁLEZ DE GARAY 


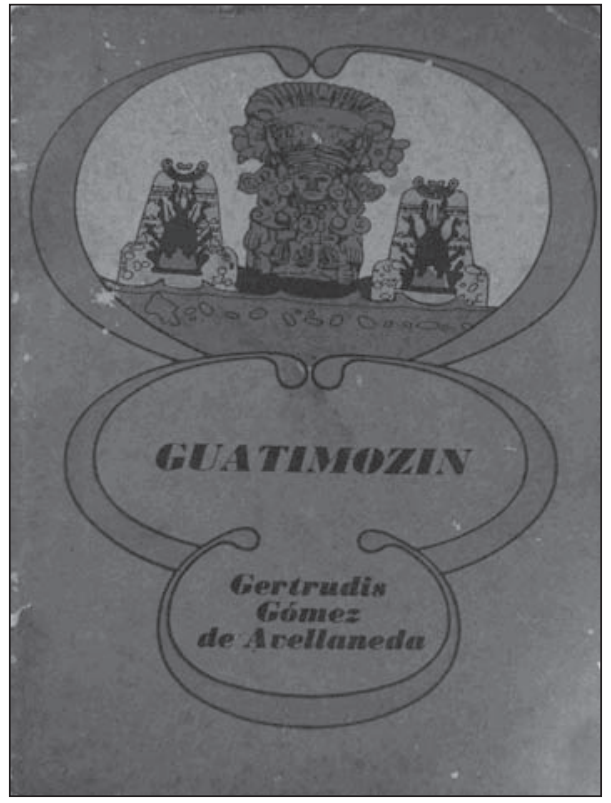

Portada de Guatimozín.

19

Fernández, op. cit., p. 75.

20

ld.

21

Castro y Calvo, op. cit., 1974, p. 229. Hay una edición moderna de 1979, con excelente prólogo y apéndices bibliográficos de Mary Cruz en La Habana (pp. 9-39 у pp. 453-460, respectivamente). Véase Gertrudis Gómez de Avellaneda, Guatimozín, último emperador de México. Novela histórica, La Habana Biblioteca básica de literatura cubana, Editorial Letras Cubanas, 1979.

Gertrudis González de Avellaneda un relato sobre Hernán Cortés

Ma TERESA GONZÁLEZ DE GARAY aunque fueran tan moderados como los que podían desprenderse de Guatimozín, último emperador de México (...) significaban una apreciación negativa de lo ocurrido en América ${ }^{19}$.

Estas palabras suponen que la novela hubiera requerido modificaciones ideológicas significativas para adaptarse a las condiciones en que se desenvolvía el género alrededor de los años 1868-1869, pero no que la autora estuviese dispuesta o no a realizarlas. Si no lo estaba, la nota editorial cumplía el papel de excusa dilatoria ad infinitum. Si lo estaba, respondía a una ineludible realidad. Lo importante es que para Teodosio Fernández, en alguna medida, sí debía estar dispuesta la Avellaneda a realizar variaciones en sentido "conservador», puesto que el crítico indica que «en este sentido, Una anécdota de la vida de Cortés también resulta significativa: en el relato se habían introducido los cambios necesarios para mostrar una imagen netamente positiva del conquistador ${ }^{20}$. Afirmación que trataremos de contrastar con el correspondiente análisis de contenidos del relato puesto en cuestión.

Pero antes parece necesario advertir algunos aspectos de la recepción en México del Guatimozín, último emperador de Méjico, que así era, en efecto, el título original de la novela. La edición príncipe, de 1846, fue reimpresa en Valparaíso (el municipio mexicano del Estado de Zacatecas) el año siguiente de 1847. Nuevamente se imprime en México capital el año 1853, edición ésta que goza de una reproducción virtual en la Biblioteca Cervantes, y más adelante, de nuevo en D.F. el año 1887, concluyendo el siglo con una traducción al inglés, editada en el propio México, el año $1898^{21}$. Este racimo de datos bibliográficos nos informa de la aceptación significativa de la obra narrativa, en las tierras que fueran aztecas, tanto en vida de su autora, como después de su fallecimiento, en 1873, a lo largo de la centuria decimonónica, siempre en el periodo posterior a la independencia mexicana. No parece haber, pues, actitudes básicas contrarias a la interpretación que la novela ofrece, tanto respecto al personaje de Hernán Cortés, como al de los indígenas nucleares del relato, desde Moctezuma al propio Guatimozín, o incluso la mujer de este último, Gualcazintla, o la más controvertida Malinche. Tal vez no se considerasen como ideales el tono y las opiniones de la narradora, pero su visión de la conquista española deviene aceptable para el lector medio mexicano. De otro modo, el texto hubiera sido olvidado, o menospreciado, como sin duda ocurrió en la España de esa misma época, donde no tenemos noticia de una sola reedición en el periodo comprendido entre 1846, fecha de la aparición, y 1873, fecha del fallecimiento de la Avellaneda. ¿No influiría también este dato en la reacción de la autora, a la hora de preparar la publicación de su obra conjunta? Sin duda alguna, las opuestas derivas nacionalistas de mexicanos y españoles en sus respectivas versiones pasionales de la conquista, de las figuras estelares de Cortés y de Cuauhtémoc, el último emperador azteca, y del sentido final del choque de ambas culturas, habían de influir en la creación literaria y en su éxito de público. Porque lo que no se podía pretender, desde 1820 en adelante, es que el Cortés de los españoles coincidiera sentimental e íntimamente con el Cortés de los mexicanos, o incluso de los hispanoamericanos en general. Ya la historia y las crónicas mantenían un pugilato, patente o soterrado, respecto a la figura del conquistador de Medellín. ¿Qué tenían que ver, en ese punto concreto, Bartolomé de las Casas y López de Gómara, pongo por caso? El primero odiaba la figura y la obra de Cortés, el segundo había sido su capellán y siempre su incondicional admirador. ¿Cómo puede extrañarnos que en el mundo de la creación literaria, y entre naciones alejadas y mutuamente resentidas, surgieran versiones opuestas y contradictorias sobre el personaje y su obra? ¿Cómo es y cómo funciona el Napoleón de Stendhal, y cómo lo hace el de Tolstoy, el de Guerra y paz, y de qué manera presenta su figura Pérez Galdós en los Episodios de la primera serie, desde La Corte de Carlos IV hasta Napoleón en Chamartín? ¿Y en qué se parece el Francis Drake de La Dragontea lopesca al Sir Francis Drake de las crónicas inglesas? ¿ $\mathrm{O}$ el Enrique VIII de Shakespeare al que presenta Calderón en $\mathrm{La}$ cisma de Ingalaterra? ¿O cómo se coordinan el Felipe II del Don Carlos de Schiller, y el que describe desde el aparente rigor científico el ensayista navarro Huarte de San Juan en su Examen de ingenios? Pero lo perecedero de la memoria histórica, para algunos de estos personajes que acabo de citar, parece que pugna con la larga duración de ciertos conflictos, 
donde están en juego «las vividuras» esenciales, en terminología de Américo Castro. Por eso tal vez, de momento, Cortés sigue vivo en su diatriba, lo mismo que Cuauhtémoc, mientras se le está acabando el tiempo a Felipe II, que durante décadas fue considerado por sus enemigos «el demonio del mediodía».

No obstante, la suerte del Guatimozín de Gómez de Avellaneda cambió de signo a lo largo del siglo XX, a partir, supongo, de la revolución mexicana. Veámoslo a través de un ejemplo sintomático. Espiguemos en el primer volumen de La novela del México colonial, obra preparada y dirigida por el Doctor Antonio Castro Leal, cuya edición data de 1964 -yo utilizo la segunda de 1965-. En las obras seleccionadas para el periodo de la conquista se incluyen, el Xicotencatl anónimo de 1826, anterior en 20 años a la novela de Gertrudis Gómez de Avellaneda, y Los mártires del Anábuac, de 1870. Dos textos decididamente anticortesianos, incluso en algún caso furibundamente anticortesianos. La primera de ellas, publicada en Filadelfia, «E.U.A.», como reza el prólogo de Castro Leal, y no USA, como hubiera rezado el de cualquier televidente español de nuestros días. Frente a la novela de la Avellaneda, estos dos textos se instalan en la radicalidad de una postura nacionalista sin fisuras, algo que nunca se hubiera permitido la escritora cubana. En el contexto sociopolítico de Antonio Castro, el mundo ideológico de la poeta de Camagüey es una antigualla, o de una insuficiente convicción. Cierto que el Doctor Castro Leal no se olvida de Gertrudis Gómez de Avellaneda y su novela Guatimozín. Pero instala la referencia al texto dentro de la «Introducción», y bajo el revelador epígrafe: «México en las novelas históricas españolas». Queda sobreentendido que la Avellaneda es española, no americana de pura cepa, y, por lo tanto, de alguna manera, también lo será la novela. A partir de esa aceptación ya no interesa desde la perspectiva estrictamente mexicana, ni puede responder a sus planteamientos rigurosos ${ }^{22}$.

De hecho, el problema va, a mi entender, mucho más lejos. Las novelas de la conquista, funcionan de modo primordial, en la literatura crítica, como exponente de posiciones ideológicas más o menos concretas, y en ellas se valora de modo singular el manejo de las fuentes documentales históricas y los valores políticos, étnicos o nacionalistas. Lo estrictamente literario sufre un relativo eclipse, o se relega a posiciones de segunda fila. Es una inevitable consecuencia del modo en que se viene abordando el género desde hace casi dos siglos. Veamos el caso de Castro y Calvo, editor de los volúmenes de la $\mathrm{BAE}$ dedicados a Gertrudis Gómez de Avellaneda. Primero entra a saco en la prosa de la autora con estas afirmaciones rotundas:

No puede leerse un ensayo, una narración o una novela de la Avellaneda sin que se produzca una sensación de tedio, de tristeza deslavazada, sin un signo noble y trágico. Si alguna vez asoma Walter Scott, queda oscurecido por una nube rosácea de novela ingenua: le falta vigor ${ }^{23}$.

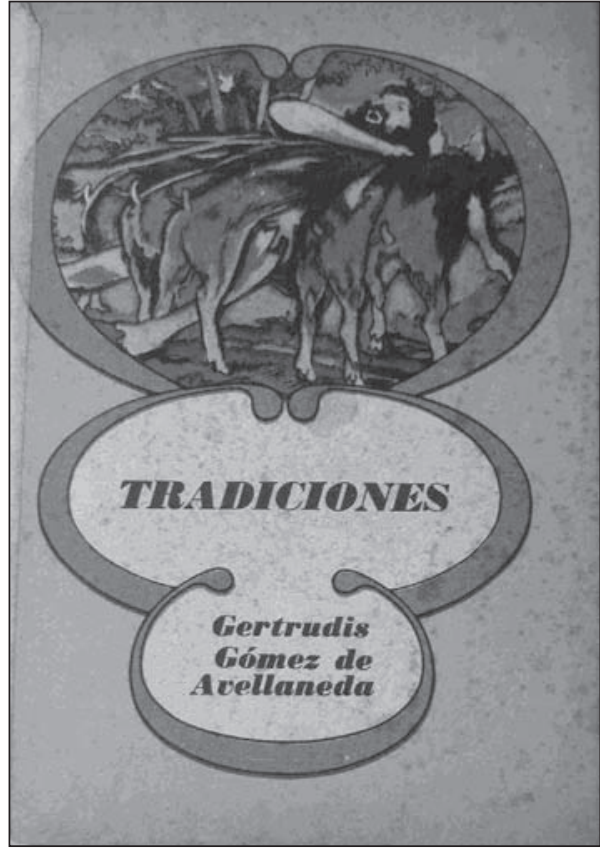

Portada de las Tradiciones de Gómez de Avellaneda.
Tras esta andanada previa, creería una que no iba a particularizar en relación con novelas concretas, pero entra en el resumen crítico de $S a b$ y de Guatimozín. Y del texto dedicado a Guatimozín, que abarca seis párrafos, cinco se dedican a indicarnos las fuentes básicas utilizadas y sintetizar los cuatro volúmenes de la edición original desde el único plano de la expedición de Cortés, que concluye con la muerte de Guatimozín, sin olvidar la referencia a las simpatías de la autora por los indígenas, sus ritos y costumbres, a los que, afirma, «describe con amor». Queda un último apartado de ocho líneas para recordar que «no falta el elemento romántico», lo que podemos interpretar como una leve alusión literaria ${ }^{24}$.

De muy diversa índole es la excelente síntesis crítica pergeñada por Teodosio Fernández en el texto ya aludido en anteriores ocasiones. Un estudio pormenorizado de las fuentes nos implica directamente en el trabajo desarrollado por la autora, y le permite al analista profundizar en los ambientes descritos, en los caracteres y en el marco narrativo desde diversos ángulos. Se trata de un muy serio intento de situar la olvidada novela en el lugar que le corresponde, tanto por sus valores históricos como por sus coordenadas literarias. Así, cuando observa que «Gómez de Avellaneda se mostró especialmente imaginativa al proponer personajes femeninos, con base histórica o sin ella, propuestos como modelos de amantes, de esposas o de madres, $\mathrm{y}$ a veces de amazonas capaces de competir en
22

Antonio Castro Leal, La novela del México colonial, Tomo I, México, Aguilar, 1965, pp. 16 , 83 y 409.

23 Castro y Calvo, op. cit., 1974, p. 211.

24 lbid., p. 218.
Gertrudis González de Avellaneda: un relato sobre Hernán Cortés Ma TERESA GONZÁLEZ DE GARAY 
25

Fernández, op. cit., pp. 72-75.

26

Castro Leal, op. cit., 1965, pp.

16-17.

27

Ibid., p. 17.

28

Castro y Calvo, op. cit., 1981, p. 207.

29

Castro y Calvo, op. cit., 1974, p. 218.

Gertrudis González de Avellaneda: un relato sobre Hernán Cortés Ma TERESA GONZÁLEZ DE GARAY coraje con los guerreros indígenas y españoles» ${ }^{25}$, sentimos la satisfacción de comprobar que, efectivamente, estamos ante una obra de ficción, con la que el posible lector puede sentirse a gusto o a disgusto, pero situado dentro de los jardines de la creación imaginativa, y no obligatoriamente adscrito a una doctrina filosófica o política. El planteamiento de Teodosio Fernández podría servir perfectamente para abrir el camino a una axiología en la que el platillo literario no quede en manos de los cronistas de Indias.

Volvamos por un momento al Doctor Antonio Castro Leal. Su referencia a la novela de Gómez de Avellaneda es, en cierto modo, excepcional. Se nos va a permitir reproducir in extenso el primer párrafo a ella dedicado, contando con la necesaria benevolencia lectora, a la que también podemos aspirar:

Es el momento de las luchas de la conquista de Hernán Cortés. Uno de los oficiales españoles, Velázquez de León, se enamora de Tecuixpa, hija del emperador Moctezuma, hacia la cual un príncipe azteca, Cacama, ha sentido siempre adoración, por más que nunca se la haya confesado. Al enterarse Cacama de los sentimientos entre Tecuixpa y el oficial español, reta a éste a un duelo, que no se realiza por intervención de Cuauhtémoc. En una batalla con los indios, Velázquez de León recibe una herida mortal y entonces, Cacama, compadecido, lo lleva a presencia de la princesa Tecuixpa para que muera al lado de su amada. Cacama se decide al fin a confesar su amor a Tecuixpa, pero se aleja de ella sin esperar respuesta. La princesa indígena, que sigue fiel a la memoria de Velázquez de León, no se casa. Cacama muere poco después a manos de sus enemigos políticos ${ }^{26}$.

Ni siquiera una alusión indirecta a Cortés y a la conquista del territorio mexicano. $Y \tan$ sólo una levísima aparición de Guatemozín, con el nombre autóctono de Cuauhtémoc, que jamás utilizó la autora. Para que no nos sintamos defraudados, Castro Leal advierte más adelante, después de asegurarnos que «la historia», (¿qué historia?) «se ha seguido con fidelidad»: «Lo que ha hecho la insigne poetisa cubana es desarrollar, paralelamente a los acontecimientos históricos, una novela romántica de amores que parecen fatalmente destinados a no cumplirse en la realidad ${ }^{27}$. La «novela romántica» es, en efecto, lo que nos ha resumido el crítico, pero sin que le haya dado opción a su autora para intervenir en el discurso ético y político de la conquista y el conquistador. Hemos pasado de uno a otro extremo. Excluyendo de los contenidos narrativos lo que no fuera ficción sentimental más o menos heroica, Castro Leal le ha hecho un flaco favor a la Avellaneda, encasillándola como «novelista romántica» y diluyendo en el vacío su compromiso riguroso con la investigación documental, con los personajes históricos y con los hechos clave de la conquista española. Tan unilateral resulta el olvido de la historicidad, con su carga polémica a cuestas, como la falta de conexión con lo ficticio, sea romántico, como en la Avellaneda, o sea racionalista ilustrado, como en el Xicotencal anónimo de Filadelfia, o sea posromántico como en Eligio Ancona. El equilibrio entre literatura e historia exige el acercamiento a ambos registros, para a partir de ellos, descubrir y escudriñar la novela concreta, como obra de creación en sí misma.

Pero quizás convenga ya, al fin, enfrentarnos en directo con el relato de la Avellaneda Una anécdota de la vida de Cortés, un relato crepuscular en la vida de la escritora, pero que retrotrae su vigencia sentimental hasta los años en que preparaba los materiales para su novela Guatimozín. Porque, como indicamos en su momento, la conexión entre ambos textos es decisiva. La anécdota, afirmaba la nota editorial, está «tomada de la novela, [y] es lo único que la autora ha querido conservar de dicha obra» ${ }^{28}$. Pero, ¿de qué parte de la novela? ¿Y esa parte, se reproduce literalmente, o sufre modificaciones significativas? Castro y Calvo asegura que el nuevo texto se refiere a «un solo capítulo, incluido en el tomo quinto, con el título Una anécdota de la vida de Cortés, relatando la 'noche triste'» 29 . Pero lo cierto es que no se trata de ninguno de los quince capítulos de la novela, sino del Epílogo, y que tampoco tiene nada que ver con «la noche triste», sino con el ahorcamiento de Guatimozín, el Cuauhtémoc de los indígenas, el Guatemuz de los cronistas, que cerraba el elenco de los emperadores o Hueitlatoanis aztecas. El desenlace del ya relativamente añejo texto -han pasado más de veinte años desde su primera publicación-es retomado por la autora, y transmutado en un brevísimo y trágico apunte de venganza, celos y horror, combinados con reflexiones éticas y políticas perfectamente meditadas. $\mathrm{Y}$ tanto los elementos patéticos como los reflexivos han supuesto una modificación sustancial del antiguo Epílogo. En lo que respecta a los elementos patéticos, la autora ha pretendido, con seguridad, mejorar el contenido textual, la estética, la estructura y la fuerza del rela- 
to, especialmente con la disminución de la verbosidad y la concentración de los efectos dramáticos. Y desde el ángulo reflexivo, que tanto interesa a un amplio sector de la crítica, el esfuerzo consciente por justificar las decisiones y actitudes del conquistador de México, Hernán Cortés, y por poner de relieve sus extraordinarias dotes personales, suponen un mentís a muchas páginas de la no reeditada novela, e incluso bordean los límites de la palinodia, otorgando así la razón a Teodosio Fernández cuando afirmaba que el relato corto pretendía, entre otras cosas, «mostrar una imagen netamente positiva del conquistador» ${ }^{30}$.

El Epílogo primitivo, por cierto, resultaba ser deudor de la novela de Salvador García Bahamonde, Xicotencal, príncipe americano, publicada en Valencia el año 1831, como respuesta «españolista» al Jicotencal anónimo de 1826, decididamente anticortesiano. Como vio muy bien Benito Valera Jácome, la Avellaneda debió conocer la novela de García Bahamonde, y sacó provecho a su lectura:

Existe una indudable coincidencia entre los dos desenlaces, con la venganza de las dos viudas indias. La viuda del jefe tlascalteca, Teutila, llega, con fingimiento, hasta la residencia del conquistador y lo hiere, lanzándole un puñal. En el epílogo de la escritora cubana, la loca viuda del último emperador finge amistad con Marina para herir a Cortés ${ }^{31}$.

Habría que añadir todavía que también utiliza un puñal robado al propio Cortés para intentar consumar el asesinato. $\mathrm{Y}$ es curioso que ese parentesco entre finales de novela, el de Xicoténcatl y el de Guatimozín, se repita en la siguiente generación, entre Guatimozín y Los mártires del Anábuac. Por supuesto, Eligio Ancona había leído el Guatimozín de la Avellaneda. Y repitió, también en el Epílogo, el ahorcamiento de Cuauhtemotzin (así lo denomina el autor) que ocupara la primera parte del Epílogo de Guatemozín. Pero en vez del intento de las viudas respectivas de acabar con la vida del conquistador español, Eligio Ancona prefirió relatar, como culminación de su Epílogo, la muerte, en Castilleja de la Cuesta, el 2 de diciembre de 1547, del frustrado Hernán Cortés: «Le habían matado -asegura el narrador omnisciente- los remordimientos, la contrariedad y el despecho» ${ }^{32}$. Se situaba así Eligio Ancona en el polo opuesto de la Gertrudis Gómez de Avellaneda de 1869.

El Epílogo de Guatemozín no ofrece divisiones externas de ninguna índole, pero su estructura interna consta de tres partes perfectamente diferenciadas. La primera de ellas describe la plaza principal «de un pequeño pueblo de la provincia de Acala» ${ }^{33}$, donde están preparadas las horcas que acabarán con la vida de Guatimozín y sus dos compañeros, y nos aclara la situación y sus motivaciones a través de la charla que mantienen «dos hermosas mujeres, ninguna de las cuales llegaba todavía a treinta años» ${ }^{34}$. Una de ellas es Doña Marina, La Malinche, la otra una andaluza «de ojos árabes y brillantes», sin duda alguna, porque no se nos aclara, mujer de alguno de los expedicionarios españoles. En esa conversación se desvelan las claves del momento histórico, y la razón por la que las tropas de Cortés, con auxiliares indígenas, se desplazan hacia una lejana provincia, llevando con ellos a los tres príncipes aztecas. La escena concluye con las palabras de Guatimozín, momentos antes de perecer en la horca, y con la aparición dramática en escena de la mujer de Guatimozín, Gualcazinla, que también acompaña a la expedición, con la razón perdida, loca desde el día que su marido, el último emperador azteca, fue torturado por orden de Cortés, tres años antes.

En la segunda secuencia narrativa, Gualcazinla, que parece haber recuperado la cordura, coincidiendo con la terrorífica visión de su marido muerto, maldice a Cortés y a La Malinche, recordando los hechos sucedidos en el periodo de la conquista, $\mathrm{y}$ termina por aceptar la invitación de Marina, que, compadecida de su estado, le insta a que vaya con ella a la vivienda de Cortés, donde podrá ser acogida y amparada. La hija de Moctezuma ha vuelto, en apariencia, a un estado de enajenación mental irremediable.

El tercer y último tramo epilogal se desarrolla en las habitaciones de Cortés y Doña Marina. Gualcazinla intentará apuñalar a Cortés en plena noche, la Malinche llegará a tiempo de impedir un segundo golpe, porque el primero había fallado por carecer de suficiente energía, y ahogará entre sus brazos a Gualcazinla, mientras Cortés huye despavo-
30 Teodosio Fernández, op. cit., p. 75

31

Benito Varela Jácome, "Evolución de la novela Hispanoamericana en el XIX», en Luis Iñigo Madrigal (coord.), Historia de la literatura hispanoamericana, Tomo II, Del neoclasicismo al modernismo, Madrid, Cátedra 1987 , p. 103

32

Antonio Castro Leal, op. cit., p. 624.

33

Gertrudis Gómez de Avellaneda, Guatimozín, último emperador de México. Novela histórica, México, Edición digital de la Biblioteca Virtual Migue de Cervantes, que reproduce la de 1853 (disponible en http:// www.cervantesvirtual.com/FichaObra.html? Ref=3623), p. 174.

34 ld.

Gertrudis González de Avellaneda: un relato sobre Hernán Cortés Ma TERESA GONZÁLEZ DE GARAY 
35

Véase Gertrudis Gómez de Avellaneda, Baltasar, Salamanca, Anaya, 1973.

\section{6}

Gómez de Avellaneda, op. cit., 1853, p. 174.

37

Castro Calvo, op. cit., 1981 p. 207

38 Ibid., p. 208.

39

ld. rido, restañándose la sangre de la cabeza. La guardia del conquistador acude, pero Cortés les dice a sus hombres que ha sufrido una caída sin importancia, provocada por una pesadilla, y les ordena retirarse. Marina y Cortés quedan en escena solos, y entonces ella le comunica que ha matado a la viuda de Guatimozín. Expresiones de pasión frenética por parte de Marina son respondidas por Cortés con la frialdad y prudencia del general en jefe. Los dos momentos claves, el del intento homicida de Gualcazinla, y el de la consumación del homicidio por Marina, se nos ofrecen en elipsis a los lectores, a través de la conversación de ambos protagonistas. No hay acción directa, sino relato oral dramatizado, una muestra insoslayable de las tendencias dramatúrgicas de la Avellaneda, cuyo género predilecto fue sin duda la tragedia de raíces dieciochescas ${ }^{35}$. Y el Epílogo concluye con la transcripción directa de un comentario de Bernal Díaz del Castillo, el cronista favorito de la autora. En realidad, lo que ha hecho Gertrudis de Avellaneda es hurgar en ese comentario y transformar lo que nunca contó Hernán Cortés, lo que, evidentemente, nunca existió, en una leyenda de amor loco, enajenación mental, que nos recuerda algunos pasajes de El doncel de don Enrique el doliente de Larra, y muerte injustificada y cruel, la de los príncipes aztecas de un lado, la de la viuda de Guatimozín por otro. Y la figura de Cortés, en el centro del cuadro, pero casi en la sombra, se proyecta con ambigüedad sobre la sangre de los muertos, como una evanescente espada de Damocles.

Una anécdota de la vida de Cortés, el relato que, en alguna medida, sustituye al Epílogo de Guatimozín, que acabamos de analizar, sí dispone de estructuración externa, en tres capítulos, con numeración romana. De los que sólo el II y el III se corresponden con las secuencias desarrolladas en el párrafo anterior. El que podemos denominar capítulo I, aunque coincida con la frase canónica inicial del Epílogo: «Tres años, poco más o menos, habían transcurrido...» ${ }^{36}$, cumple una función diversa, de introducción histórica y narrativa al núcleo dramático, y de base silogística y argumentativa para esclarecernos las características personales y los valores humanos de Hernán Cortés. Ese capítulo I, si no hagiográfico, es, por lo menos, ampliamente justificatorio de la conducta del conquistador extremeño. Y no sólo desde el plano particular de los hechos acaecidos durante la campaña de México, antes y después del sitio y toma de la capital, sino también desde el plano universal del fatum heroico, de la impronta del genio sobre el ominoso pelotón de los mediocres. En el área concreta de la expedición contra los aztecas, el narrador en tercera persona, trasunto ideológico de la autora, se esfuerza en convencer al lector de que el ánimo de Cortés, hubo de plegarse, aun con sufrimiento interior evidente, y cito al pie de la letra, "ante las exigencias de su feroz soldadesca y de las bárbaras numerosas huestes auxiliares, colocadas bajo su bandera por la ciega república tlascalteca y otros pueblos americanos» ${ }^{37}$. Esas exigencias son ahora la clave que permite defender la memoria de Cortés contra los ataques de sus detractores, los de entonces, los del propio tiempo de la conquista, los de tres siglos después, durante el periplo vital de la Avellaneda, e incluso los de hoy mismo. Pero es en el plano general donde se afianza con la máxima intensidad el alegato a favor de Cortés, porque -indica el narrador-

nunca se ejerce impunemente la superioridad del genio... Al levantarse las grandes individualidades de todos los siglos, de todos los países, siempre encuentran hostiles a las numerosas medianías... De este modo toda vida eminente, de iniciativa vigorosa, viene a ser continuado combate empeñado con la resistencia del orgullo colectivo.... ${ }^{38}$.

Para llegar a la esperada conclusión:

Hernán Cortés, una de las mayores figuras que puede presentar la historia; Hernán Cortés, que quizás no ha sido colocado a su natural altura, ni aun por desacertados encomiadores... Hernán Cortés, digámoslo en fin, debía tener y tuvo la suerte común a todos los genios superiores. Persiguiólo la envidia, afanóse por denigrarlo la calumnia, acecháronlo la deslealtad y la perfidia... ${ }^{39}$.

Era necesaria, a mi juicio, la cita extensa, para dejar resuelto el dilema. No sólo se ha modificado sustancialmente el desenlace de Guatimozin al convertirlo en relato independiente, sino que se le ha inyectado una carga ideológica de signo muy distinto a la que pudiera estar presente en la primitiva novela. No me atrevo a decir que de signo opuesto, porque permite el escepticismo sobre la ideología de Gertrudis Gómez de Avellaneda en 1846, es decir, permite sospechar que la Avellaneda de 1846 carecía de ideología definida respecto al tema de la conquista americana, y se dejaba guiar simplemente por sus lecturas, y por su temperamento. En esas páginas con que se 
abre el relato que comentamos estamos ante un texto nuevo, que jamás hubiera podido incluirse en el Epilogo de Guatimozín, y que parece conectar con los desvaríos de Rodión Romanovich Raskólnikov en las páginas de Crimen y castigo, o más a ras de tierra, con una fugaz explosión del nacionalismo alarconiano, que en fechas cercanas a la redacción del texto de la Avellaneda, pergeñaba las páginas de Diario de un testigo de la guerra de África.

Lo que queda del capítulo I tras el excursus filosófico-político es, simplemente, una referencia a los antecedentes de la tragedia final, que en el Epílogo primitivo estaban presentes en el conjunto de la novela, y que para el relato corto debían precisarse al máximo, con objeto de otorgarle una coherencia razonable. Había que explicar los motivos que llevaron a Cortés a emprender la expedición a Honduras, los porqués de que en ella incluyera a los príncipes, con Guatimozín y su esposa Gualcazintla (ahora la Avellaneda ha añadido una «t» a su nombre indígena), prisioneros desde la caída de Tenoctitlan, y dar cuenta sucinta de los rumores de conspiración de los prisioneros contra Cortés y los suyos, que desencadenaron la condena a muerte de Guatimozín y el que en el relato pasa por ser su hermano, el rey de Tacuba. Por cierto que en el Epílogo de la novela los condenados a la horca eran tres, y no dos: Guatimozín, Netzale, rey de Tacuba, y Coanacot. La disminución del número de ajusticiados favorece, sin duda, la causa de Cortés para la autora, aun cuando en este caso hay que decir que se ajusta a la Historia verdadera de Bernal Díaz del Castillo ${ }^{40}$ y a la Quinta Relación de Hernán Cortés ${ }^{41}$, dos de las fuentes básicas consultadas y seguidas por la Avellaneda. Sin pasar por alto el importante detalle del aspecto físico de la Princesa, que en el Epílogo destacaba por su figura «lastimosa», «triste y sombría», pero que ahora, en la nueva versión, «a la que tres años de cautiverio y de inenarrables infortunios, no habían podido despojar de su peregrina belleza» ${ }^{42}$. Preparando con esta maniobra habilidosa las mutaciones decisivas de la escena última del drama. Todos estos factores -estéticos, éticos e históricos- forman el entramado del capítulo I de este texto narrativo, y dan paso al nudo propiamente dicho, y al inesperado desenlace.

El capítulo II es el que más se asemeja a la vieja secuencia narrativa de 1846 . De nuevo tenemos a las dos mujeres, Marina y la andaluza, que ahora tiene nombre, Doña
Guiomar, aunque siga sin conocerse su filiación personal, contemplando el espectáculo desde el mirador del viejo templo azteca, con el patíbulo a la vista, y hablando sobre el tema, sus protagonistas y sus implicaciones. El diálogo se ha reducido, se ha concentrado, ha ganado así en intensidad y fuerza, como ya insinuamos en su momento, pero también ha perdido los filos de la acusación contra el jefe, contra el Malinche, como le llama Doña Marina. Y, para muestra baste un botón, ha desaparecido en su totalidad el comentario decisivo del narrador:

Marina acababa de dar con estas palabras la única explicación probable del hecho que vamos a referir, la única excusa verosímil de un acto de crueldad que inmotivado sería horroroso y que en vano quisiéramos justificar apoyándolo en la sospechosa acusación de un súbdito traidor, que no obtuvo crédito ni entre los mismos españoles, por más que aparentase Cortés prestárselo completo ${ }^{43}$.

La táctica de diluir la culpa de Cortés continúa siendo uno de los fundamentos del texto reformado, seguramente el decisivo, la raíz última de su escritura. También se ha modificado con intención el discurso en el cadalso de Guatimozín. Mientras en el Epílogo da irónicamente las gracias a los españoles por la piedad que les han dispensado, y exclama: «Muero inocente aunque se me haya condenado a la muerte de los facinerosos. ¡Hernán Cortés! Dios te demande cuenta de esta sentencia» ${ }^{44}$, la Anécdota se limita a expresar: «Proclamo de nuevo mi inocencia a la faz del cielo y de la tierra» ${ }^{45}$. Quedó eliminada la invocación a Dios contra Cortés, y ello a pesar de las palabras que en su boca puso Bernal Díaz del Castillo, perfectamente conocidas, de otra parte, por la Avellaneda: «¡Oh capitán Malinche! Días había que yo tenía entendido e había conocido tus falsas palabras, que esta muerte me habías de dar, pues yo no me la di cuando te entraste en mi ciudad de México; ¿por qué me matas sin justicia? Dios te lo demande» ${ }^{46}$. Entre el comentario del narrador y las palabras del emperador se condensaban los principales elementos del texto de Bernal en el Epílogo de la novela. Todo se ha borrado en la Anécdota. El capítulo II concluirá en el momento en que la viuda de Guatimozín acepta el ofrecimiento de Marina y va a hospedarse con ella en los aposentos de Cortés, tras la tensa conversación entre ambas, que, como en el Epílogo, se solventa con un inesperado y sorpresivo cambio de opinión por parte
40 Bernal Díaz del Castillo, Historia verdadera de la conquista de Nueva España, Madrid, Alianza Editorial, Sociedad Quinto Centenario, 1989, p. 708.

41

Hernán Cortés, Cartas de relación, Madrid, Castalia, 1993, p. 564.

42

Castro y Calvo, op. cit., 1981, p. 208.

43

Gómez de Avellaneda, op. cit., 1853 , p. 176

44

Id.

45

Castro y Calvo, op. cit., 1981, p. 211.

46

Díaz del Castillo, op. cit., p. 708.

Gertrudis González de Avellaneda: un relato sobre Hernán Cortés $M^{a}$ TERESA GONZÁLEZ DE GARAY 
47

Castro y Calvo, op. cit., 1981, p. 212.

48

ld.

49

Ibid., p. 213.

50

ld. de Gualcazintla. La conversación presenta numerosas variantes en la Anécdota respecto al Epílogo, pero tal vez no merezca la pena insistir en los detalles. Solamente subrayar los apelativos insultantes de «manceba» y «querida» con que Gualcazintla fustiga a Marina, porque están sin duda contribuyendo a la preparación de la escena decisiva.

Y entramos, al fin, en el capítulo III, donde se han producido ampliaciones sustanciales en el desarrollo primitivo de la secuencia última del Epílogo, y una transformación radical de los acontecimientos dramáticos. Por de pronto, el intento por parte de Gualcazintla de asesinar a Cortés está presente en todos sus detalles, la elipsis primitiva ha desaparecido. Pero ese intento viene precedido de una serie de reflexiones sobre el ánimo y los sentimientos de Cortés, que armonizan con los objetivos que se trazó la autora para elaborar la Anécdota. El lugar de los acontecimientos es ahora, que no en el desenlace de la novela larga, el que fuera templo de la diosa Meztli, personaje del panteón azteca que, la autora nos lo aclara en nota, como acostumbra en otras ocasiones en el Guatimozín de 1846, era la deidad que presidía la noche. Un detalle espacial muy del gusto romántico, porque las estatuas de la diosa aún permanecen en pie en el salón que comunica la estancia de doña Marina, adonde ésta ha conducido a la viuda de Guatimozín, con la de Cortés. Un detalle, nos atreveríamos a decir, estrictamente teatral, y un lugar perfecto para la venganza de la emperatriz, hija del humillado Moctezuma. Doña Marina presenta a Cortés a su «huéspeda» y le ruega que le dispense «particular amparo». Y observa «la viva y grande impresión causada en el ánimo de Cortés por sólo la presencia de aquella hermosura infortunada» ${ }^{47}$. Doña Marina, posesiva y desconfiada, enlaza la impresión a la hermosura, que ya tuvo la autora buen cuidado de subrayar con anterioridad. Pero, por su parte, el narrador omnisciente, nos informa de que

las crueldades que la conveniencia hacía cometer o consentir al jefe del ejército español, hallaban en su propio noble corazón secreto pero inmediato castigo, y bajo la influencia del sentimiento que le oprimía desde que creyó necesidad inevitable el sacrificio de sus dos más ilustres prisioneros, no pudo menos de demostrar a Gualcazintla -como para acallar un tanto su conciencia- un afecto tan expresivo y tierno, que llegó a alarmar a la enamorada y celosa Marina ${ }^{48}$.
Y de este modo, frente al remordimiento de Cortés, se instalan los celos de la amante. A nosotros se nos informa de que Cortés se siente culpable, pero a Marina no. Y este es el juego que van a jugar los dos personajes en el tramo final.

La noche avanza y el insomne Cortés sale desde su alcoba al salón y se pasea convulsivamente por él, «en medio de las toscas estatuas de la diosa que presidía a las sombras, y a las cuales apenas alumbraba la opaca luz de una lejana lámpara ${ }^{49}$. Hemos remontado desde el romanticismo de panteón al goticismo del castillo de Otranto. Pero es ahí donde quería llegar la autora. Al momento en que surge de esas sombras ominosas "negro fantasma», y retrocede Cortés «con el cabello erizado por supersticiosa pavura». El «héroe» pregunta al espectro su identidad, y éste le responde (en qué lengua, nos preguntamos inevitablemente): «Soy la venganza... y vengo a exterminarte, tirano» ${ }^{50}$. El espectro esgrime en su mano «el bruñido acero de una daga» y resulta ser, al fin, la viuda de Guatimozín, que logra herir en la frente a Cortés, pero sin la necesaria firmeza. No se arredra ni «flaquea» el español, y desarma a Gualcazintla, aprisionándola entre sus brazos. Acaba de poner sobre el tapete la Avellaneda el tópico del espectro, de sólida trayectoria dramática, tanto en Shakespeare, Hamlet, como en Lope, El caballero de Olmedo, y que también tuvo vida en el romanticismo español, tanto en el campo lírico, Espronceda en El estudiante de Salamanca, como en el teatral, Zorrilla y las dos partes de El puñal del godo. Como tal espectro es siempre de carácter patético, cuando no trágico, pero como «fantasma», puesto que así lo califica también la autora, suele acercarse a las fronteras de la comedia, como en Dickens y su Cuento de Navidad, o regodearse con virtuosismo en ella, al estilo del Calderón de La dama duende y El galán fantasma. De «la fantasma» hablaban nuestros clásicos, como ocurre en el caso de Castillo Solórzano y su delicioso relato La fantasma de Valencia. Gómez de Avellaneda ha utilizado el tópico con maestría, en una situación límite, y coordinando así venganza, muerte, pasión, celos y culpabilidad, en un apretado nudo gordiano, que estallará por el punto más débil: el de La Malinche. Marina no contemplará el ataque de la viuda de Guatemozín, descubrirá a Cortés, cuando éste haya devuelto a su habitación a Gualcazintla, y creerá de inmediato que su amante está aprovechándose de la hipotética demencia de la viuda "para gozar su 
hermosura», como, en un clásico lenguaje de teatro calderoniano, le increpa a Cortés con ira, cuando éste ya se está lavando la herida en su habitación, y Marina penetra como un vendaval para zaherirle y vilipendiarle. Para entonces Marina ya estuvo en la habitación de Gualcazintla, donde la había dejado Cortés tras el intento de asesinato, y la había ahogado entre sus manos, para impedir, le asegura a Cortés, que siga «mancillando el tálamo de la viuda del emperador de Méjico, antes de que se haya enfriado el cadáver de Guatimozín» ${ }^{51}$. Marina amenaza a Cortés con la «justicia del cielo» por su delito, y entonces el general, tras rechazar a Marina, le enseña la herida de la frente, y le dice: «La suprema justicia, con que me amenazáis, acaba de impedir que terminase mi vida miserablemente a manos de una mujer frenética, aunque menos que vos.... ${ }^{52}$. La defensa de Cortés por Marina en el Epílogo, que de alguna manera justifica el exceso de la Malinche, en plena lucha, ahogando a Gualcazintla, mientras Cortés, ensangrentado, sale de la estancia para detener a los soldados de su guardia, que acudían atraídos por los ruidos, es ahora, en la Anécdota, una «fría», o «hirviente», decisión de la amante de Cortés, arrastrada por los celos y por la furia $\mathrm{y}$ el despecho de quien no tolera compartir «los favores» de su amado. En el Epílogo hay un principio de cooperación, de ayuda mutua, entre Cortés y doña Marina, que termina en la muerte de Gualcazintla. En la Anécdota, doña Marina actúa sola, sin conocimiento de Cortés, y carga sobre ella toda la culpa del luctuoso acontecimiento. Lo que se gana en nervio trágico de amor y celos, también se gana en deslindar culpabilidades últimas, para que Cortés quede limpio de esta última muerte.

Pero sí se repite en ambos textos la cita de cierre. La de Bernal Díaz del Castillo tras la ejecución de Guatimozín:

Andaba Cortés mal dispuesto y pensativo después de haber ahorcado a Guatemuz y a su deudo el Señor de Tacuba, sin tener justicia para ello, y de noche no reposaba; e pareció ser que saliéndose de la cámara donde dormía, a pasear por una sala en que había ídolos, descuidóse y cayó, descalabrándose la cabeza; no dijo cosa buena ni mala sobre ello, salvo curarse la descalabradura, e todo se lo sufrió callando ${ }^{53}$.

Una cita parcial e inexacta, pero que mantiene con esa parcialidad e inexactitud, literalmente sin la más mínima variación, en el Epílogo y en la Anécdota. Porque Díaz del Castillo lo que asegura es que Cortés anda mal dispuesto, pensativo "y descontento del trabajoso camino que llevábamos» ${ }^{54}$, aun cuando influyan además en su estado de ánimo las condenas de los príncipes aztecas «sin tener justicia para ello», ahí la Avellaneda transcribe con exactitud, y el hambre que pasa su ejército y las enfermedades y muertes de españoles y mexicanos que le acompañan. En esta ocasión la escritora ha decidido, por el bien estético y ético de su relato, que el texto manipulado de Díaz del Castillo continúe vivo.

El análisis comparado entre ambos textos, que hemos venido denominando Epílogo y Anécdota, de 1846 y 1869 respectivamente, ha ido definiendo con bastante precisión la existencia de dos momentos diversos, e incluso divergentes, en la mentalidad de la Avellaneda respecto a la figura histórica y humana de Hernán Cortés. Pasamos así de un Cortés astuto, frío, ambicioso y dispuesto a sacrificar vidas ajenas, si ello conviene a sus intereses políticos y militares, el de la novela Guatimozín, a un Cortés modelo de fidelidad a su rey, heroico en sus acciones, excepcional en su audacia, y personaje universal de primera magnitud. Pasamos también de un Cortés sin corazón, a un Cortés que se arrepiente de sus errores y que lamenta las consecuencias de algunos de sus actos. De un Cortés grande, pero cruel, a un Cortés calumniado y envidiado por los mediocres. Pero no conviene extrapolar desde el personaje concreto a la acción colectiva. Del texto último que acabamos de estudiar no se deduce que la Avellaneda modificara sus criterios sobre el tema de la conquista americana en su conjunto. Simplemente, lo que queda claro es la transformación de sus opiniones sobre Hernán Cortés. El resto, habría que discutirlo desde otras premisas y con otros argumentos textuales, y no podemos ahora entrar en ello. Pero sí, en cambio, importaría, como pequeño colofón de nuestro estudio, contribuir a iluminar dos aspectos narrativos del Guatimozín y su secuela: el de la aparición de la Malinche como protagonista femenina en el Epílogo y la Anécdota, tras haberla olvidado por completo durante el desarrollo del Guatimozín, y el uso de las citas y referencias a Crónicas y cronistas de Indias, como confirmación de la verdad histórica de los hechos narrados. Lo intentaré con la máxima brevedad. Parece evidente que doña Marina no le resultó propicia a la novelista para su incorporación como figura clave a la historia de la conquista
Gómez de Avellaneda, op. cit., 1853, p. 178.

54 Díaz del Castillo, op. cit., p. 709.

Gertrudis González de Avellaneda: un relato sobre Hernán Cortés $M^{a}$ TERESA GONZÁLEZ DE GARAY 
Gómez de Avellaneda, op. cit. 1853, p. 179.

56

Id.

57

Castro y Calvo, op. cit., 1981, p. 213.

58

Díaz del Castillo, op. cit., p. 602.

59

Hugh Thomas, Quién es quién de los conquistadores, España, Salvat Editores, 2001, p. 71. Y Juan Miralles, Hernán Cortés. Inventor de México, Barcelona, Tusquets editores, 2001, pp. 464-65.

60

Margo Glantz, La desnudez como naufragio. Borrones y borradores, Madrid, IberoamericanaVervuert, 2005, pp. 43-44.

Gertrudis González de Avellaneda: un relato sobre Hernán Cortés Ma TERESA GONZÁLEZ DE GARAY mexicana. Ha preferido a la dulce Tecuixpa, otra hija de Moctezuma, para relatarnos sus románticos deliquios con Velázquez de León. Como también se refiere, a través de los datos ofrecidos por Marina en el Epílogo, a la fidelidad a toda prueba de Teutila, princesa de la Casa de Tezcuco, a su esposo Netzale, rey de Tecuba, uno de los ejecutados por orden de Cortés junto a Guatemozín. Teutila fue robada a su esposo azteca por Andrade, uno de los hombres del vencedor, y obligada a casarse con él. Es en tales conflictos amorosos interraciales, en el desgarro sentimental del choque de culturas, en el enfrentamiento entre la pasión, la seducción, la violencia y la atracción amorosa, con personajes femeninos sin base histórica, donde se encuentra a gusto la Avellaneda. Pero no era ese el caso de doña Marina. Marina no sólo es un personaje histórico, sino que cumplió en los avatares de la conquista un doble papel polémico y odioso: el de amante del jefe español, y el de intérprete, «la lengua», le llama siempre Bernal Díaz del Castillo, en las conversaciones entre españoles e indígenas, con la sospecha siempre de convertirse en delatora, y traidora, por tanto, a sus compatriotas. Sólo al final, para marcar de modo fehaciente la tragedia de Guatimozín y la muerte de su viuda, al amparo de Cortés, doña Marina se convierte en un personaje imprescindible. Y no duda entonces en utilizarlo la novelista, enfatizando con la máxima intensidad la pasión imperiosa de la Malinche por Hernán Cortés, que se expresa al mismo nivel que la de Melibea por Calixto en el Epílogo: «Es que tú eres mi Dios», le dice al guerrero español, para concluir afirmando: «Yo no soy más que eso, una mujer loca de amor por ti» ${ }^{55}$. Esta explosión de retórica amorosa quedará en la Anécdota limitada a una explosión virulenta de celos. Pero en ambos textos Marina se referirá a su matrimonio, impuesto por Cortés: «Sé que debo fidelidad al marido que me habéis dado", le espeta en el Epílogo; "harto también he torturado y envilecido mi alma recibiendo -porque así lo exigisteis- marido de vuestra mano", le grita en la Anécdota. Y lo que es más curioso, en ambos textos Cortés está también casado, y Marina le advierte que «cuido de no dar disgustos a la feliz mujer que lleva vuestro nombre» ${ }^{56}$, o "harto he sufrido ahorrando quejas a la dichosa mujer que lleva vuestro nombre» ${ }^{57}$. Curioso, porque mientras en el caso de Marina, el matrimonio, por orden o no de Cortés, se acababa de realizar durante la expedición a Honduras, muy poco tiempo antes de la ejecución de Cuauhtémoc, como relata con su habitual naturalidad Bernal Díaz del Castillo: «Dejemos de hablar en el factor y sus blandas y delicadas palabras, y diré cómo en el camino, en un pueblezuelo de un Ojeda 'el tuerto', cerca de otro pueblo que se dice Orizaba, se casó Juan Jaramillo con doña Marina la lengua delante de testigos» ${ }^{58}$, en el caso de Cortés tal matrimonio no existía. Los hechos relatados en ambos textos acontecen en el año 1525, y la primera mujer de Cortés, Catalina Suárez, había fallecido en 1522. Con su segunda mujer, Juana de Arellano y Zúñiga, contraería matrimonio, tras el primer retorno a España, el año 152859. El supuesto matrimonio de Cortés es una invención de la Avellaneda, supongo que para añadir al amancebamiento con Marina, o en su caso, al adulterio, una mayor dosis de interés novelesco. Pero, en cualquier caso, la tardía, aunque decisiva, aparición estelar de la amante de Cortés, formó parte desde el principio, del proyecto narrativo de la Avellaneda. Recuerda Margo Glantz, en el capítulo de su libro La desnudez como naufragio, titulado «La Malinche: la lengua en la mano», que sólo una vez, precisamente en la Quinta Relación, «la llama Cortés por su nombre: Marina, la que yo siempre conmigo he traído», y que logra convertirse en secretaria y faraute de Cortés, porque, «recuerda Bernal, es de buen parecer, entremetida y desenvuelta» ${ }^{60}$. Ahí en sus lecturas, se encontró Gertrudis de Avellaneda con Marina, o la lengua, y de ahí la rescató para volverse loca de amor por Hernán Cortés.

Sólo dos de las nueve notas que introduce la Avellaneda en la Anécdota se refieren a los cronistas de la conquista mexicana. La primera procede de la Tercera Carta de Relación de Cortés, y ya había aparecido en el Guatimozín, en el capítulo XIV. La segunda estaba incluida en el Epílogo, era la 104 y última de la novela, y precisaba las opiniones de Bernal Díaz del Castillo respecto a la hipotética conspiración que llevó a la horca a Guatimozín y al rey de Tacuba, «su deudo», como expresa el cronista, y no su hermano como asegura la novelista. De las variadas fuentes que aparecen citadas en el conjunto de la novela, quedaban en pie las dos más significativas, la del propio Cortés y la de Bernal, su eterno y siempre huraño compañero de fatigas. La carrera epistolar o cronística era ardua. Respecto a Cortés, Margo Glantz nos recuerda: «Es revelador que sus Cartas de Relación fueran prohibidas desde 1527 y quemadas en las plazas públicas 
de las ciudades más importantes de España. Es también muy significativo que la historia de López de Gómara haya sido censurada poco tiempo después de que se escribiera. Cortés supo definir las nuevas condiciones de la sociedad que ayudó a construir; su sagacidad y constancia para descubrir los secretos de la tierra y calar hondo en las cosas de su tiempo lo convirtieron en un hombre peligroso: su poder amenazó quizá al de la monarquía» ${ }^{61}$.

¿Y qué decir de la Historia verdadera de la conquista de Nueva España? ¿La que salía al paso de las falsedades y los olvidos de la obra de López de Gómara, el capellán de Cortés? Citemos a Reynolds: "Su Historia verdadera de la conquista de Nueva España fue concluida en 1568, pero no publicada hasta $1632 »^{62}$. Cuarenta y ocho años después de la muerte de su autor, sesenta y cuatro desde su composición, un siglo desde la caída de Tenoctitlán. Por lo visto, no debía ser nada fácil estar de acuerdo con la persona y la obra de Cortés. $\mathrm{Ni}$ en el siglo XVI, ni en el siglo XX. Margo Glantz, excelente novelista e historiadora mexicana del siglo XXI, de hoy mismo, lo confirma y lo subraya. Y también Susana Montero en su monografía $\mathrm{La}$ Avellaneda bajo sospecha ${ }^{63}$. ¿Por qué, en nombre de qué, le vamos a exigir fidelidad en las ideas, coherencia en sus juicios, continuidad en sus visiones ficcionales, firmeza filosófica y ética en el devenir de su pensamiento histórico, a Doña Gertrudis Gómez de Avellaneda?

Bastante tiene la inolvidable Tula con aguantar la búsqueda de nuevas manifestaciones epistolares de sus debilidades amorosas o de sus pasiones secretas de folletín decimonónico ${ }^{64}$. Por eso me parece necesario concederle un respiro y otorgarle el beneficio de la duda.

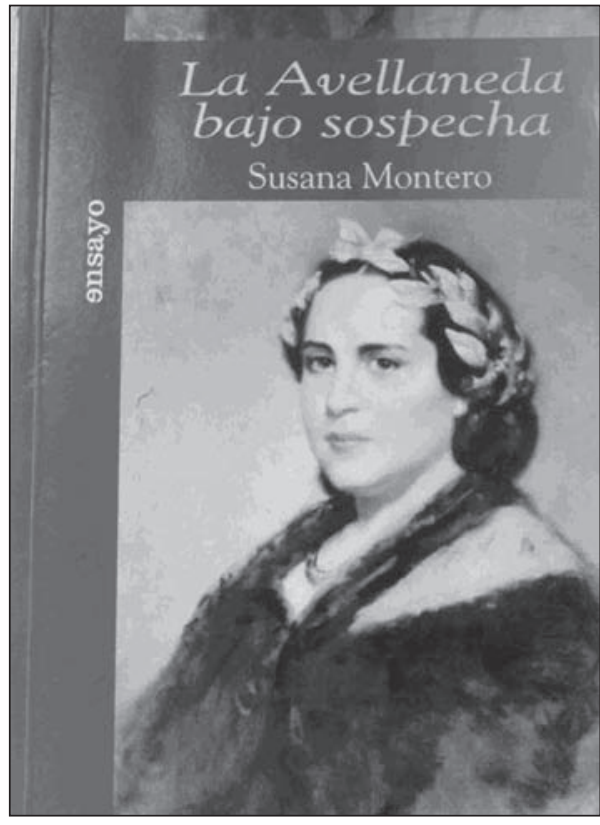

Portada del libro de Susana Montero La Avellaneda bajo sospecha.
61 Ibid., p. 25.

62 Reynolds, op. cit., p. 68

63

Susana Montero, La Avellaneda bajo sospecha, La Habana Editorial Letras Cubanas, Instituto Cubano del Libro, 2005, p. 105. Véase asimismo el estudio de Carolina Alzate Cadavid, Desviación y verdad. La re-escritura en Arenas y la Avellaneda, EE.UU., Society of Spanish and Spanish-American Studies, 1999, especialmente el capítulo 3, «Gertrudis Gómez de Avellaneda: transgresión feminista, exceso y ambigüedad», pp. 139-237.

64

Gertrudis Gómez de Avellaneda, Poesías y epistolario de amor y de amistad, Madrid, Instituto de la Mujer, Castalia, 1989. Y Nora Catelli, El espacio autobiográfico, Barcelona, Lumen, 1991. 